\title{
My Life as a Globe-Trotting Solo Entrepreneur
}

\author{
Sarah Lempa (Sarah Lempa) \\ Daniel Forbes (University of Minnesota, Carlson School of Management)
}

\section{KEYWORDS: Entrepreneurship, Marketing, Strategy.}

Entrepreneurship comes in different forms, and the experience of being a solo entrepreneur - or a "company of one"

(https://eiexchange.com/content/39-entrepreneurshipprograms-should-nurture-compani?search=Gendron) is a form that's attracting a great deal of interest today. In this Q\&A we talk to Sarah Lempa, who took the plunge and has spent the last several years building a career for herself as a freelance writer and creative media strategist. Sarah graduated in 2018 with a marketing major from the University of Minnesota's Carlson School of Management. Here, she talks about her drive to do her own thing and her "locationindependent" lifestyle, which has included stretches of time in Vietnam, Bali and Australia.

\section{EIX: Tell us about the work you've done since leaving college.}

While I've worn many hats in my career, I am primarily a writer and creative media strategist (https://www.sarahlempa.com/) . After graduating college, I hopped on a one-way flight to Vietnam with the ultimate goal of creating a location-independent career. Since then, I've worked my way across six continents juggling the joys of self-employment and travel in the process.

A typical to-do list of mine is chock-full of social media management; email marketing design, myriad writing assignments, and the occasional website project. One minute, you might find me drafting witty Instagram captions, whereas the next l'll be brainstorming a seasonal ad campaign. It really just depends on the day.

In addition to ongoing client work, I write for various publications whenever an exciting idea strikes me. My bylines have appeared in Business Insider, Fodor's Travel(https://www.fodors.com/news/author/sarahlempa) , Seeker(https://seeker.io/day-trips-frommelbourne/) , and SUITCASE Magazine (https://suitcasemag.com/travel/stories/worlds-collide- russian-vietnamese-city/) . Most of the brands I work with operate in the travel industry, but l've also delved into hospitality, wellness and events. Regardless of the topic, I've had the great pleasure of helping my clients tell their stories through countless mediums.

\section{EIX: How does your post-graduation experience compare to what your classmates have done?}

As my classmates walked across the graduation stage with full-time offers and set plans for their post-college lives, I found myself facing the great unknown with an endless sea of question marks. Engaging in the pursuit of far-flung dreams is paramount in life - but let's be real, it doesn't always offer financial stability in the initial stages. I took a big risk compared to my classmates. There was no fallback plan (unless you can count my parent's couch). With my student loan grace period ticking away and bills coming regularly, the stakes were even higher. By September of 2018, most of my friends had started their roles at companies across the U.S., whereas I found myself tinkering with shoddy Wi-Fi while living off of $\$ 1.25$ bowls of pho [noodle soup] in Vietnam.

\section{EIX: How do you think your experience has been harder? How has it been easier or better?}

Creating your own personally tailored career structure is one of the most challenging things l've ever done and I'm still learning more every day. Don't be fooled by the photos of palm trees and white sand beaches; they don't tell the entire story. For the first time in my life, I found myself with zero structure or guidance. It felt whimsically magnificent at first - the world had opened up more than ever. It was an unbridled freedom that I had never quite experienced before. The journey is anything but linear, however. Even the euphoric aspects of this lifestyle can bring their own detriments: fleeting anxiety, loneliness while on the road, self-questioning and doubt; the list goes on. Not to mention, the learning 
curve of starting your own venture is quite steep, especially as a fresh graduate. Some of the hardest days of my entire life have occurred in the past two years, yet also many of the best. It has truly been a wild ride and I wouldn't have it any other way.

I can't think of any ways this experience has been easier than the alternatives - but there are infinitely many ways that it has been a better fit for me. Not only have I gotten to see the world and help small and startup businesses grow, l've also gotten to grow personally in many different ways. Obvious perks like choosing when to work and the projects I take on are still beyond thrilling to me, but it is the personal development and pure elation of having "my own thing" that makes me smile the most. Sometimes I get so excited about projects that I end up staying up until 3 a.m. and I always look forward to chatting with clients and colleagues. Oftentimes, it doesn't even feel like work.

\section{EIX: What advice would you give to someone who wants to explore an entrepreneurial career in creative domains?}

I have to hand it to them: Nike was onto something when they coined the phrase "just do it." The sooner you can get started experimenting with small projects, the better. Whether you invent your own or reach out to small businesses in your area, laying the foundation for a solid portfolio is key. Be specific and confident about how you can add value to their organization. Don't be afraid to approach people you admire, either. I reached out to many folks when I was getting started to learn about their career paths. Basically, if I saw someone and thought, "what they do is awesome; l'd like to do something like that," I would make a point to reach out. Just be mindful of their time. Asking a few questions over email will probably be better than expecting a call or meeting right off the bat, but most entrepreneurs are quite passionate about their craft and happy to connect.

And lastly, don't be discouraged if you don't know exactly what your strong suits are. When I was getting started, I tried my hand at as many different creative mediums as I could. One day I thought I might pursue graphic design; the next might day have been photography, followed by web development ... the list went on. It's perfectly okay to not know; that's what you're going to figure out. It just takes time!
EIX: Sometimes people in creative work have to choose between what's practical and what they consider ideal, or their "dream" work. How, if at all, has this choice presented itself for you?

Absolutely. It can be a tough choice to make. At times, I felt inadequate for graduating without a full-time offer. When everyone around you is updating their Linkedln titles and you're Googling random coworking spaces in Hanoi instead, it's easy to question yourself. And for a while I did just that - quite a bit. To be honest though, I simply saw no other option. I either had to try and succeed or try and fail. Either way, I had this insatiable curiosity and taking the "safe route" wasn't going to answer any of my questions. I don't think there's anything wrong with choosing a more practical route at all; it really just comes down to your individual preferences and what will make you happiest.

I wouldn't stress too much about the structure right off the bat. Any bit of experience will be of benefit, even if it ultimately tells you "okay, maybe I don't like this exact structure and I need to try something new." I had a lot of that. Instead of seeing not-so great experiences as a waste of time, I now view them as learning tools.

\section{EIX: What other lines of work did you consider?}

Since one of my biggest priorities was having the freedom to travel, I considered being a flight attendant while continuing to build a creative "side hustle" in my spare time. I actually made it to round 3 of the interview process but ultimately didn't end up receiving an offer. I was crushed at the time, but now I realize it couldn't have possibly been a better outcome. I actually applied to a bunch of different opportunities during my last semester in college - mostly marketing jobs - but none of them panned out. In retrospect, l've never been more grateful for rejection letters.

\section{EIX: What prompted you to move internationally, and how has that affected your entrepreneurial career?}

Experiencing other cultures and places around the world has always been one of my number one passions. I had a bit of a nomadic childhood, even traveling and living in an RV for a few months at one point. Movement is my mojo. I find the world far too fascinating to stay in one place, anyway. Starting in Southeast Asia was a 
strategic move for my financial situation at the time though; I knew my funds would last me longer there compared to at home in the United States. I wanted to buy myself more time to grow my client list and also experience a new place. Since reaching full-time status, I've chosen destinations solely based on appeal. Living in Australia certainly wasn't cheap, but I loved it there.

Entrepreneurially, this decision has presented some challenges - time zone gymnastics, Wi-Fi woes, and trying to balance work and exploration in a sensible ratio, to name a few. Overall, it has been a massive benefit as I've gained in-depth knowledge about many countries and I mostly work with travel companies. I've learned so much from my friends around the world (about both business and life in general) and I couldn't be more grateful. Regardless of being an entrepreneur, I firmly believe travel makes you a better person and I'll take the challenges for that.

\section{EIX: What's next for you?}

That's a great question! In short: I have so many ideas. I would love to get into public speaking and develop a coaching sector of my business to help others cultivate a lifestyle that feels custom built for them. I've already worked with some aspiring entrepreneurs one-on-one (https://www.sarahlempa.com/learn-how-to-freelance), but l'd like to develop a more organized class or program. In regards to public speaking, it would be amazing to work with universities and academic institutions to share my experience with students who might feel similar to how I did in college. Ultimately, I feel this big desire to help others, and I'm not quite sure what it's going to turn into but l'm really excited for what the future holds. I have also considered expanding my freelance business into a full-service digital agency, but that's on the back burner for now.

Oh, and I aspire to write a book someday. That's a "next decade" list item though. 